\title{
Corrigendum: Using Zebrafish to Model Autism Spectrum Disorder: A Comparison of ASD Risk Genes Between Zebrafish and Their Mammalian Counterparts
}

\author{
Victoria Rea and Terence J. Van Raay* \\ Dept of Molecular and Cellular Biology, University of Guelph, Guelph, ON, Canada
}

Keywords: ASD, autism, genes, behavior, zebrafish, human, mice

\section{A Corrigendum on}

Using Zebrafish to Model Autism Spectrum Disorder: A Comparison of ASD Risk Genes Between Zebrafish and Their Mammalian Counterparts

by Rea, V., and Van Raay, T. J. (2020). Front. Mol. Neurosci. 13:575575.

OPEN ACCESS

Approved by:

Frontiers Editorial Office,

Frontiers Media SA, Switzerland

*Correspondence:

Terence J. Van Raay tvanraay@uoguelph.ca

Received: 14 April 2021 Accepted: 16 April 2021 Published: 13 May 2021

Citation:

Rea V and Van Raay TJ (2021)

Corrigendum: Using Zebrafish to Model Autism Spectrum Disorder: A

Comparison of ASD Risk Genes

Between Zebrafish and Their

Mammalian Counterparts.

Front. Mol. Neurosci. 14:695317.

doi: 10.3389/fnmol.2021.695317 doi: 10.3389/fnmol.2020.575575

In the original article, Mueller et al. (2011) and Mueller (2012) were not cited in the article. The citation has now been inserted in Figure 1 legend, and should read:

Figure 1. Comparison of homologous regions of the (A) zebrafish (B) mouse and (C) human brains. Am: amygdala; Ce: cerebellum; Ctx: cortex; Dp: dorsal pallium; Hip: hippocampus; Lp: lateral pallium; Mp: medial pallium; Th: thalmus; Vp: ventral pallium. Zebrafish image in (A) adapted from Mueller et al. (2011) and Mueller (2012).

The authors apologize for this error and state that this does not change the scientific conclusions of the article in any way. The original article has been updated.

\section{REFERENCES}

Mueller, T. (2012). What is the thalamus in zebrafish? Front. Neurosci. 6:64. doi: 10.3389/fnins.2012.00064

Mueller, T., Dong, Z., Berberoglu, M. A., and Guo, S. (2011). The dorsal pallium in zebrafish, Danio rerio (Cryprinidae,

Teleostei). Brain Res. 1381, 95-105. doi: 10.1016/j.brainres.2010.12.089

Copyright $\odot 2021$ Rea and Van Raay. This is an open-access article distributed under the terms of the Creative Commons Attribution License (CC BY). The use, distribution or reproduction in other forums is permitted, provided the original author(s) and the copyright owner(s) are credited and that the original publication in this journal is cited, in accordance with accepted academic practice. No use, distribution or reproduction is permitted which does not comply with these terms. 